\title{
Decolonised and Africanised Texts: A Higher Education Perspective
}

\author{
Linda Scott
}

Vaal University of Technology, South Africa

\begin{abstract}
South Africa has undergone and continues to undergo dramatic changes on the educational landscape, particularly in higher education institutions (HEIs). The latest drive for decolonisation and Africanisation of the curriculum emanated from the 2015 student protests (\#FeesMustFall; \#RhodesMustFall). Decolonisation and Africanisation are not new concepts and are practices required to ensure that changes are carried out on curricula that are colonial and Eurocentric and which perpetuate Western bias. The research question deals with: What approaches need to be considered when developing strategies for editing of decolonised and Africanised texts in higher education in South Africa? The objectives of this study included understanding the reasons for delay in implementing decolonised texts; an analysis of educator and editor roles and perspectives on the phenomenon of decolonisation of higher education texts, and uncovering possible editing strategies and approaches that could assist in the development of a framework for the standardisation of the process of decolonisation and Africanisation in higher education texts. The approach of this study is from an editing perspective with a qualitative, interpretive research paradigm. Although this study is cross-sectional, it forms part of a longitudinal study into understanding strategies and developing guidelines to decolonise and Africanise texts in HEIs in South Africa. Data for this study were collected from a literature review of editing strategies when decolonising and Africanising text. As there is a shortage of available literature in South Africa, editing practices for indigenous texts formed the unit of analysis for this study. In addition, empirical data were collected on the perceptions of educators in a South Africa HEI on, inter alia the extent and the process of decolonisation and Africanisation of the curricula. The findings of the study revealed a number of editing strategies and themes that could be useful in understanding and developing a framework for the process of decolonisation and Africanisation of texts. Conclusions are provided and limitations for the study are delineated. Further
\end{abstract}

Keywords: decolonisation, editing, curricula, South Africa

\section{Introduction}

Even though the 2015 student riots at universities in South Africa, known as \#FeesMustFall and \#RhodesMustFall, are credited with the implementation of a number of changes in universities, student protests have been ongoing as far back as 1994 (Davids \& Waghid, 2016). Previously, student riots were in historicallydisadvantaged universities such as Cape Peninsula University of Technology, Fort Hare University and Tshwane University of Technology (Davids \& Waghid 2016); however, the 2015 protests, specifically by the University of Cape Town's students, highlighted the frustrations of the students about the lack of adequate transformation. This transformation was not expected to take place overnight, but emanated from the fall of the apartheid system in 1994. Students demanded the removal of Cecil John Rhodes' statue (SAHO 2015) and once the statue was removed, debates continued on race relations, funding and access thereof, as well as revitalising the movement to decolonise education. Unlike the previous riots at historically-disadvantaged universities, students from both historically-advantaged and -disadvantaged universities joined these protests and the move to decolonise and Africanise the curriculum began in earnest.

Jansen (2017, p. 2), while acknowledging the "significant progress in transforming institutional curricula" with examples such as the influential African Law programme at the University of Pretoria and the Southern African history programme at the University of the Free State, continues by stating that there is a large amount that could still be done to incorporate a "Pan African influence across the university curriculum". The author also refers to how the curriculum in some Afrikaans universities continues to be influenced by the apartheid era, 
while English universities are reluctant to change a curriculum centred on the theorists like Bernstein and Bourdieu (Jansen, 2017).

\section{Background and Rationale for the Study}

According to Le Grange (2016, p. 1), the discussions on decolonisation are long overdue. The colonial curriculum that many universities practice is considered as "racist lens of inferior, incompetent, incapable states and individuals who required the colonial power to give the natives civilization through education, religion, governance and infrastructure" (Jansen 2017, p. 5). Decolonisation and Africanisation, embedded in African knowledge and achievement from a buried past should be at the centre of the curriculum in South African HEIs.

In an effort to understand the delay in implementing a decolonised and Africanised curriculum in HEIs in South African and find suitable editing strategies for editing the texts in HEIs, this study examines three different aspects of the problem. The first section attempts to understand why the change has been delayed; the second section undertakes to examine educators' perspectives on the process, while evaluating their role in the process versus the role of editors and, finally, the third part looks at ways to optimally offer socio-cultural commitment to the implementation of a decolonised, Africanised curriculum.

While many authors have attempted to contextualise the terms decolonisation and Africanisation (MacGregor, 1996; Makgoba, 1997; Odora Hoppers, 2000; Horsthemke, 2004; Le Grange, 2016; Ndlovu-Gatsheni, 2016), this study recognises the devastation brought about by colonialism. As stated by Thiong'o (1986, p. 390), “its important area of domination was the mental universe of the colonised, the control, through culture, of how people perceived themselves and their relationship to the world ... to control a people's culture is to control their tools of self-definition in relationship to others". The author postulates that in an effort to correct that and create an African-centred curriculum, decolonisation should be undertaken within the mindfulness of Africanisation as "a conscious and deliberate assertion of nothing more or less than the right to be African" (Ramose, 1998, iv).

\section{Problem Statement and Research Question}

It is clear from the literature on decolonisation and Africanisation in South Africa, that this has been a slow process. It is also clear that strategies need to be investigated in order to create a framework within which decolonisation and Africanisation of texts in HEIs should take place. It is acknowledged that this is not going to be an easy process and different strategies need to be tested to ensure suitability. It should also be borne in mind that there is a constant threat of re-colonising texts due to the previous Eurocentric educational system under which current academics and editors studied.

Alexis Wright (2002) refers to editors as "gatekeepers for communities" and states that editors are the "gatekeepers of what is flowing in and out of our communities". This is certainly true for educators, who are required to instil knowledge into the students they teach; they become the gatekeepers and have the power to grant access to the knowledge required to promote an African-centred curriculum, as opposed to the previously Eurocentric influences.

As previously mentioned, this study forms part of an ongoing, longitudinal study with the aim of developing strategies and guidelines for stakeholders of decolonised and Africanised texts.

The research question posed by this study is: What approaches need to be considered when developing strategies for editing of decolonised and Africanised texts in higher education in South Africa?

\section{Approach to the Study}

Social science is shaped by two "overarching ontological positions ... realism and idealism" and this study is qualitative, based on the position of realism because "[r] ealism is based on the idea that there is an external reality which exists independently of people's beliefs about or understanding of it" (Ritchie, Lewis, Nicholls \& Ormston, 2013, p. 4). An interpretive approach is adopted because, as stated by Ritchie et al. (2013, p. 12), the production of knowledge is due to the researcher:

- $\quad$ exploring and understanding the social world of the people being studied, focusing on their meanings and interpretations 
- constructing meanings and interpretations based on those of participants.

In addition, the value of constructionism is recognised as it places emphasis on knowledge being "actively 'constructed' by human beings, rather than being passively received by them” (Ritchie et al., 2013, p. 12).

\section{Research Methodology}

According to Strauss and Corbin (1990), "[g]rounded theory is adopted as the general methodology for developing theory that is grounded in data systematically gathered and analyzed". The authors note that there is a constant interplay between analysis and data collection and the approach is referred to as a constant comparative method.

In understanding decolonisation and Africanisation, there needs to be constant data collection and analysis until the possible approaches that will be optimal for decolonising and Africanising in South Africa are reached.

This study can be divided into three parts. The first part of this study involved the scrutiny of the literature and research undertaken to discover the reasons for the delay in implementing a decolonised and Africanised curriculum in HEIs in South Africa. The second part of the study involved cross-sectional, qualitative research using purposive, snowball sampling at universities in South Africa. Participants were required to be involved in curriculum development at the university. The data collected were analysed to gain an understanding of the perceptions of educators regarding decolonisation and Africanisation of the curriculum. In addition, a theoretical study of the literature to correlate the roles of editors versus educators responsible for curriculum development was carried out. In the third part of the study, the literature was critically reviewed, not only to verify approaches to decolonising but also to discover strategies previously implemented to deal with decolonising and/or Africanising of texts. Due to the shortage of studies conducted in South Africa, the researcher turned to the literature from other countries that have experienced decolonisation.

\section{Part 1: Reasons for Delays in Change}

To understand why change has been so long in coming, it is necessary to understand the factors that have hampered the call for change as well as the role of stakeholders in the process of change. An examination of the reasons must start with the history of South Africa, thereafter, the problem of linguistic hegemony is discussed and then a brief discussion on the process of decolonisation.

\section{South African history}

A brief overview of South African $20^{\text {th }}$ century history relevant to the problem (South African Government, 2019) brings us to the realisation that change is long overdue.

1910: The creation of the Union of South Africa, which was essentially a white union leading to the inevitable black opposition in the form of the African National Congress (ANC)

1943: The launch of the ANC Youth League, which gave rise to later leadership in the forms of Nelson Mandela, Oliver Tambo and Walter Sisulu.

1948: The National Party (NP) comes into power, which leads to the rise of apartheid with its rigorous, authoritarian approach to segregationist policies.

1949: The ANC adopts a Programme of Action with renewed militancy and calls for action against white domination in the form of protests, strikes and demonstration.

1950s: The Defiance Campaign, the first large-scale, multi-racial political mobilisation against apartheid laws (under the leadership of the ANC, South Indian Congress and Coloured People's Congress) mobilises.

1960: The Sharpeville massacre of 69 PAC demonstrators, the declaration of a state of emergency and implementation of detention without trial. 
1961: Prime Minister HF Verwoerd, leader of the NP, declares South Africa a republic after winning a whitesonly referendum. The enforcement of segregation and different legislations veiled in the ideology of racial purity become concerning. 3.5 million people are subjected to forced removal and division into ethnic 'nations', with their own 'homelands'.

1976: (June) The beginning of a sustained anti-apartheid revolt with the uprising of Soweto school pupils, followed by youth uprisings countrywide.

1980s: Limited reforms are implemented by government, such as allowing coloureds and Indians limited participation in parliamentary houses and the scrapping of pass laws.

1994: The first democratic election is held after pressure from business, students, academics, a failing economy and international pressure leads to the fall of apartheid.

1999: After a period under the interim Constitution with a government of national unity including the NP, Ikatha Freedom Party and ANC the ANC wins the second democratic election.

2014: Despite progress in reducing rural poverty and increasing access to basic services in rural areas, many areas are still characterised by poverty and inequality.

2019: 25 years have passed since the first democratic elections and students are still calling for a decolonised, Africanised curriculum to be presented in schools and universities, which finds its grounding in the indigenous knowledge systems.

So, why after all these years, are there still 'talks' about decolonising and Africanisation? Maybe, as stated by Ndlovu-Gatsheni (2016), it is that "decolonization of the state did not translate into decolonization of universities in Africa into African universities". Is the focus on the "why' instead of the 'how'? Do we know 'how' to decolonise? The changes that have already occurred in the higher education landscape should not be minimised - there have been many, but this article is borne from a question of 'how' should the process be conducted and what the role of the academic is in the process of decolonisation and Africanisation of curricula.

\section{Linguistic hegemony}

The British landed in the Cape in the $19^{\text {th }}$ century and introduced English to South Africa, however, the Dutch community had already established themselves in the Cape and were opposed to English (Scott, 2015, p. 30) English became known as "die vyand se taal" (the language of the enemy) (Silva, 1997). Many years of linguistic hegemony, shifting between the fight for superiority by English and Afrikaans followed, none of the other languages mattered.

Alexander (2011, p. 7) refers to the language policy and planning in post-apartheid South Africa as having "exhilarating potential and great expectations being squashed at regular intervals". At the beginning of the language dispensation arbitration process there were two sides - the one side comprised the white minority (mostly National Party members) wanting to retain English and Afrikaans as official languages and the other side was the forces of liberation (mostly ANC members) who wanted English as the only official economic and political language (Alexander 2011, p. 7). The South African black elite were of the opinion that English proficiency would be responsible for liberation, freedom, incorporation and empowerment (Alexander 2011, p. 7); the leaders at that time could have chosen English as the only official language but they could not justify not including the indigenous languages as it would have reflected the adoption of a neo-apartheid language policy (Alexander 2011, p. 7). Hence, the 11 official languages of South Africa came into being, namely Sepedi, Sesotho, Setswana, siSwati, Tshivenda, Xitsonga, Afrikaans, English, isiNdebele, isiXhosa and isiZulu. Silva (1997, p. 2). Silva (1997, p. 2) opines that English was a powerful language and it retained its dominance as the language of higher education, commerce, science and technology, and communication.

\section{The process of decolonisation}

Ramose (2004, p. 138), questions the construction of a "truly South African philosophy of education", which has been denied to the indigenous people for over three centuries. He states that the epistemology and philosophy of the colonialists dominated the educational curriculum, as the "colonial conqueror" did not see the need to include an African philosophy in the educational curriculum (Ramose, 2002, p. 5). 
Le Grange (2016) states that "decolonisation is not an event but a process and it is not necessarily easy to achieve". Laenui (2006, p. 1-7) referring to the Hawaii societal experiences and the process of decolonisation, identifies five phases of decolonisation. These phases follow the process of colonisation, which include the steps of denial and withdrawal; destruction and eradication; denigration, belittlement and insult; surface accommodation and tokenism and, finally, transformation and exploitation (Laenui, 2006, p. 1-7). Decolonisation processes include five different phases for the person or society, that could occur at the same time or in different combinations and these are rediscovery and recovery; mourning; dreaming; commitment; and, finally, action (ibid).

General society in South Africa is in, or has gone through, the phase of rediscovery and recovery in the 25 years since the fall of apartheid. The phase of mourning has been evident in the establishment of the South African Truth and Reconciliation Commission (TRC) (2018), which was recommended by Mr Dullah Omar, former Minister of Justice, on the basis that "a commission is a necessary exercise to enable South Africans to come to terms with their past on a morally accepted basis and to advance the cause of reconciliation." However, society and individuals may still be going through their own personal mourning phases but Laenui (2006, p. 4) cautions against "abuse of the mourning phase [that] can turn into an attempt to entrench the colonization in order to continue the mourning". The dreaming phase is crucial for decolonisation and in this phase, people are able to re-discover their culture and dreams for the future, which will shape their action plans. Commitment takes the form of release from the colonial shackles and all stakeholders make a commitment to the dreams, which will ensure action takes place. Finally, action takes place when commitment is reached and incorporates the choice of the people (ibid). To undertake this final phase of action in decolonisation and Africanisation of the curricula, we need to examine the history and culture of the country from the perspective of indigenous people.

The phase of action should be conducted to ensure that the South African phenomenon of decolonisation and Africanisation of the curriculum, specifically from an editing perspective, is conducted within a framework that is established from the contributions of all stakeholders.

\section{Part 2: Educator Perspectives}

This section of the research reviewed the demographics of a South African classroom; thereafter, the perceptions of educators relating to the process of decolonisation was examined and the section culminated in a number of themes being identified after the analysis of the replies received from educators in the questionnaire.

\section{Considering the demographics of the HEI}

It is important to consider the demographics of the HEI when decolonising and Africanising the curricula. The South African higher education classroom is filled with students from diverse backgrounds and ethnic groups, speaking many different languages. Notwithstanding the fact that South Africa has 11 official languages, English has retained its position of dominance as the lingua franca in the classroom.

Globalisation has a profound influence on the use of language in HEIs. According to Block and Cameron (cited by Coleman, 2006, p. 1), globalisation is "a complex phenomenon, with positive and negative social impacts, embracing economics, culture, identity, politics and technology." Coleman (2006, p. 3) states that today a globalised market owns higher education. With this globalisation comes the need to adopt a common language of instruction and the adoption of English is often the natural course of action because of its global status (Coleman, 2006, p. 4).

To understand the complex demographics of higher education in South Africa, the following tables provide insight. Table 1 shows that out of approximately $57 \mathrm{~m}$ people, $46 \mathrm{~m}$ are Black Africans. 
Table 1 Mid-year population estimates for South Africa by population group, 2018

\begin{tabular}{ll}
\hline Population Group & Total \\
\hline Black African & 46682900 \\
\hline Coloured & 5074300 \\
\hline Indian/Asian & 1448300 \\
\hline White & 4520100 \\
\hline Total & 57725600 \\
\hline
\end{tabular}

Source: Statistics South Africa (2018)

There are 461 HEIs in South Africa with the student enrolment in excess of 2.2 million (Department: Higher Education and Training, 2017).

From Figure 1 it can be seen that Black African enrolment in public HEIs far exceeds any of the other groups.

HEI ENROLMENT - 2015

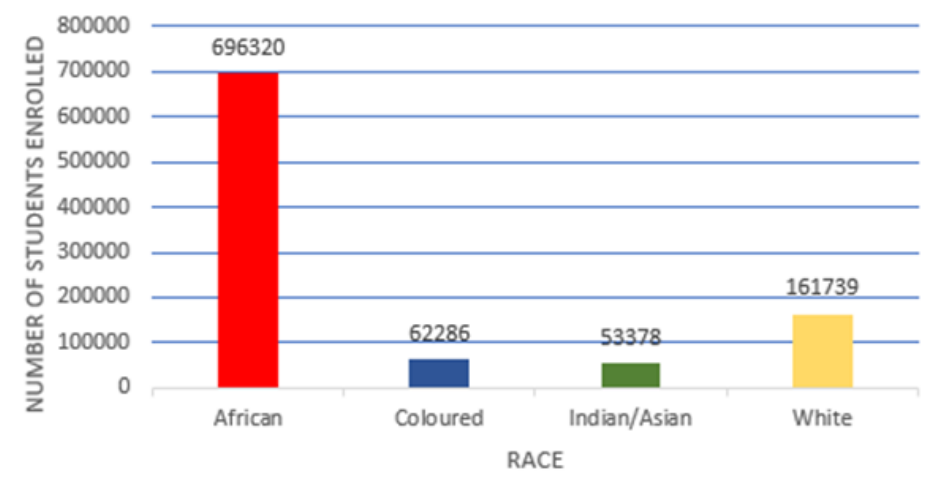

Figure 1: Public HEI enrolments by race in South Africa (2015)

Source: Compiled from information available from Department: Higher Education and Training (2017)

Figure 2 provides information from a South African HEI classroom (Scott 2015), where it is noted that from the classroom of 40 students, all 40 speak English and other languages. Many of the students are multilingual and it is not unusual for students to speak English and Afrikaans, then have, for example, a Zulu mother and Sesotho father, enabling the student to speak both Zulu and Sesotho.

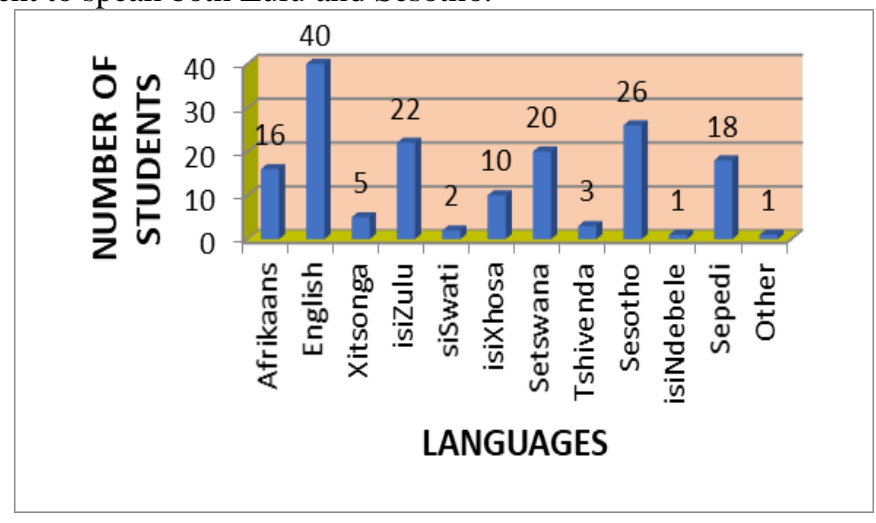

Figure 2: HEI classroom survey

Source: Scott (2015)

This study recognises the educator as playing a role in editing of texts for students' use. The Business Dictionary (2019) defines editing as "[a]rranging, revising, and preparing a written, ... material for final production" with the objective of “... removal of factual, grammatical, and typographical errors, (2) clarification 
of obscure passages, (3) elimination of parts not suitable for the targeted audience". This definition clarifies the role of editor and when compared with the role of educator in the HEI classroom, the educator is seen as preparing documents for production by ensuring that the texts are suitable for the targeted audience; hence, acting as editors (gatekeepers) of texts to which students will be exposed.

Kehdinga and Fomunyam (2017) believe that "to begin to decolonise teaching and learning, one must be cognisant of how teaching and learning is enacted; what is used to facilitate the enactment of the same; who facilitates it; and how what is facilitated is accessed". In this section, the researcher attempted to understand the perceptions of educators, specifically those involved in curriculum development and research and their views on the progress of Africanising and decolonising curricula. The educators were from South African universities and snowball sampling was used. Participants were requested to answer questions regarding decolonising and Africanising the curriculum. Participants came from different faculties such as Information Technology, Management Sciences, Electrical Engineering, Marketing and Sports Management and Languages and different universities such as the University of South Africa, the Vaal University of Technology, the University of Pretoria and Central University of Technology. Anonymity was guaranteed for participants and participants could choose to withdraw from the study at any time.

Demographics of participants

The demographics of the study for gender (Figure 3) show that there were 68 percent female and 32 percent male participants for the study.

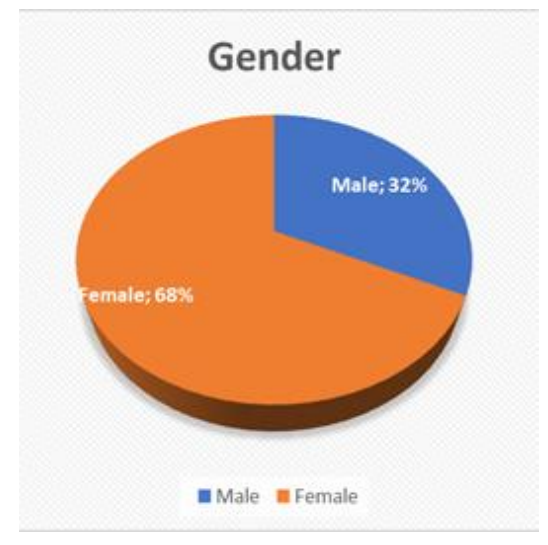

Figure 3: Gender

The ages of the participants ranged from 21 to +60 years with the highest number of participants $(32.4 \%)$ being in the 31 to 40 age range.

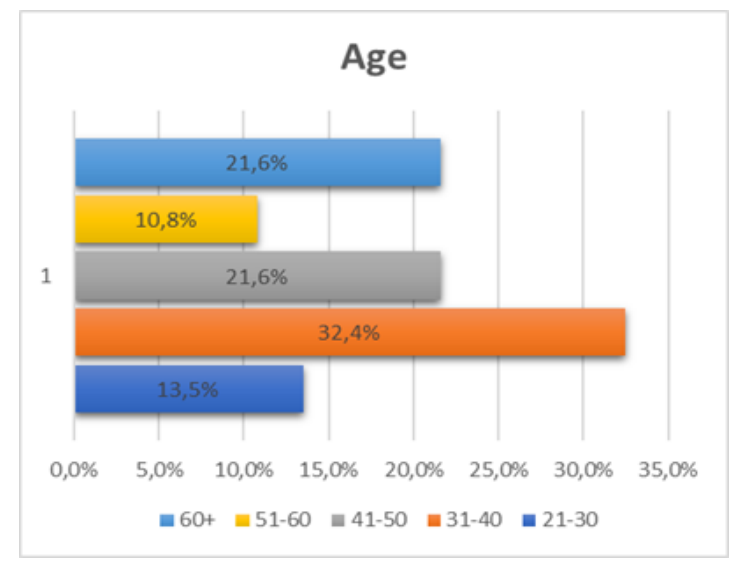

Figure 4: Ages of participants 
Black Africans made up the majority of the participants (62.2\%), followed by Whites (37.8\%) (Figure 5). These participants claimed that 35.1 percent had Afrikaans as their first language, 18.9 percent Other languages, 16.2 percent isiZulu, 13.5 percent Sesotho, 5.4 percent Setswana and 2.7 percent spoke Xitsonga (Figure 6).

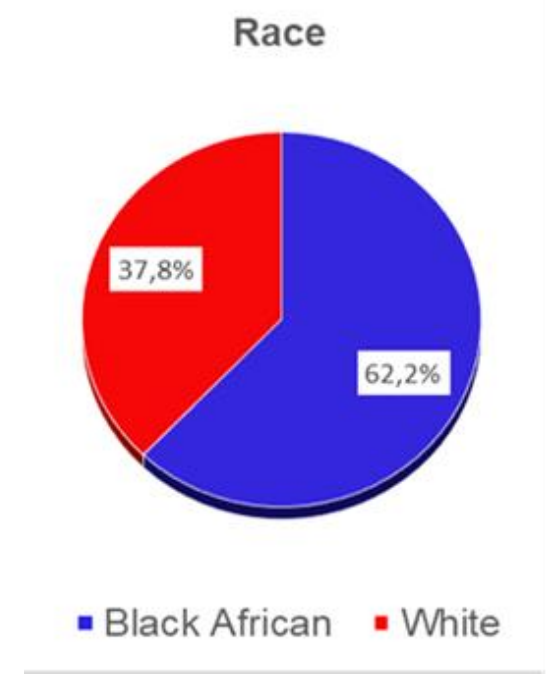

Figure 5A: Race

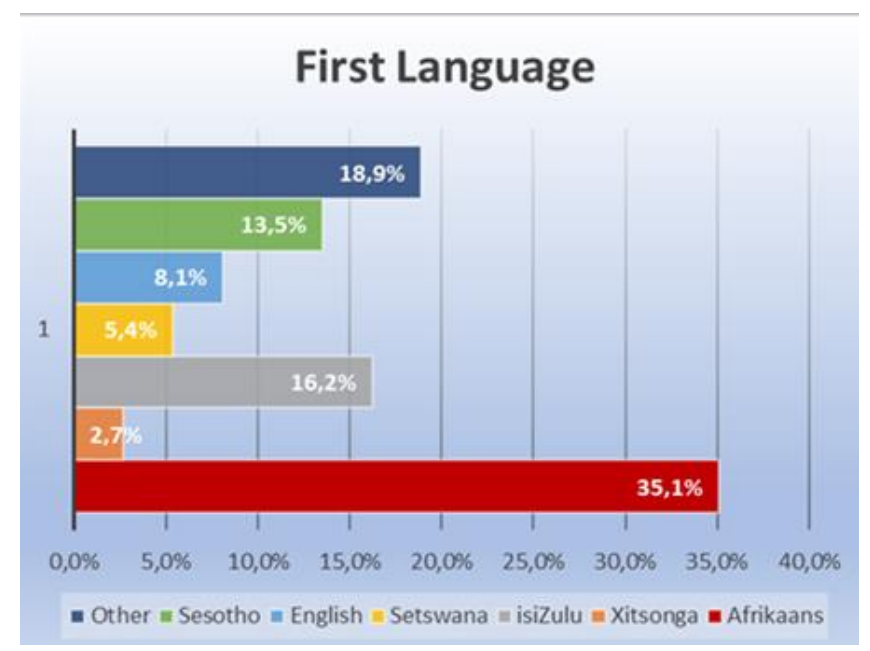

Figure 5B: First language of participants

Perceptions of change in the department

Participants were questioned on the matter of decolonising their department

Relating to their departments, only 27.8 percent of participants believe that the curriculum has been decolonised and the new curriculum implemented, 22.2 percent state that they are currently working on decolonising the curriculum and that some sections are already implemented, 19,4 percent state that they are currently working on decolonising, but no changes have yet been implemented, 13,9 percent note that there are no plans in place for their departments to start decolonising the curriculum and 16,7 percent believe that this is not relevant to them or their subject.

Participants were asked about the progress for Africanising the curriculum within their departments.

$13.9 \%$ of the participants believe that the curriculum in the department has been Africanised and the new curriculum implemented, 27.8 percent note that they are currently working on Africanising the curriculum and some sections have already been implemented, while 8.3 percent say that they are working on this but nothing has been implemented yet. An equal number of participants $(16.7 \%)$ believe that the department will start 
working on Africanising the curriculum in the near future, there are no plans in place in their department to Africanise, or it is not Africanising is not relevant to themselves or their subject.

Participants were asked to give their opinion on research in their department and what they promote regarding research. The options for answers are listed in Table 3.

Only 27 percent of participants are encouraging their student to lean towards Africanising their research projects, 24,3 percent were planning to encourage their students, $13,5 \%$ had no plans yet but will consider this for the future, 5,4 percent do not believe the content should be Africanised and 29,7 percent stated that they do not deal with research so it is not relevant to them.

Even though a number of participants did not believe there was a need for change or had not started to implement change, many made recommendations when asked to give a brief description on methods to decolonise and Africanise the curriculum and research projects. Four distinct themes emerged for these suggestions and they were categorised as follows:

\section{Theme 1: It's not my problem}

"I don't plan to use decolonisation".

"Decolonisation to me is theory and hard to implement unless the entire society transforms"

"Decolonisation won't change the content of the subject that I am lecturing"

\section{Theme 2: Draw attention to African issues}

Suggestions from participants included but were not limited to:

"Encourage postgraduates to incorporate the topic into their research if possible"

"Encourage my postgraduate students to align their research studies with African subjects"

"Arranging seminars on decolonisation of curriculum"

"I try to use examples from African culture to explain concepts"

"I encourage them to study African literature"

\section{Theme 3: Use local content and local examples}

Suggestions from participants included but were not limited to:

"Suggesting local editions of research publications and textbooks"

"Provide students with relevant (decolonised learning material)"

"Content changes need to be more relevant to the current student population, enabling them identify and relate better to the content of the curriculum".

"Use examples from African traditions or life style"

"Encourage more research with a local twist, yet without entirely dismissing theories and foundational teachings and methodologies from the Western world because despite decolonisation, it is necessary for postgraduate students to understand their role and position in a global world"

"Encourage the use of local data from renowned African scholars and other portals". 


\section{Theme 4: Encourage collaboration with local and international organisations}

Suggestions from participants included but were not limited to:

"Benchmarking with international universities"

"Collaboration with local and international hospitality institutes"

"Consultative meetings with different stakeholders".

Even though no new themes emerged and data saturation was considered to have been reached when the same four identified themes continued to emerge, it is recognised that a larger, more far-reaching study, perhaps comparing institutions, may give rise to new themes. According to Fusch and Ness (2015, p. 1408), it is preferable to think of data as rich and thick data, where rich refers to quality and thick refers to quantity "[t]hick data is a lot of data; rich data is many-layered, intricate, detailed, nuanced, and more". The answer to having enough data is to ensure you have enough of both thick and rich data.

Part 3 of the study involved an investigation into how educators and/or writers could ensure socio-cultural commitment issues in decolonised texts in HEIs. These strategies are highlighted because as either writer or editor, the educator needs to have some form of measure on whether a text has been decolonised sufficiently.

\section{Part 3: Socio-Cultural Commitment to Decolonised and Africanised Texts}

\section{Use of proverbs}

Chinua Achebe's novel, Things Fall Apart, provides some examples of writing that portrays socio-cultural commitment. An analysis by Bamisile (2008) of the novel reveals that the writer has roles and responsibilities to society. Achebe notes that the writer has a social responsibility as he/she is seen as the spokesman for society. He refers to writers as educators, visionaries, critics, agents of change and historians, all of these are roles that the educator would be undertaking (Bamisile, 2008, p. 77). He also refers to the commitment of African writers as ensuring their works are the tools of education and they should "teach their readers about the rich cultural patrimonies of the African past" (Bamisile, 2008, p. 78).

Techniques used in Achebe's novel include the use of proverbs - these give deep meaning to a text, as proverbs are valuable in Africa. They are regarded as tools to "guide human behaviour, describe human nature, explain natural occurrences, and teach basic societal beliefs" (Bamisile, 2008, p. 84). In addition, the value of proverbs in the classroom is encouraged, especially to encourage critical thinking and creative writing. They serve as images, symbols and metaphors while providing deeper meaning in text (ibid).

\section{The development of a model for ethical cross-cultural author-editor relationships}

Freeman (2009, p. 133), specifically referring to the position non-indigenous editors find themselves in when editing indigenous writing, claims that editors find themselves navigating the uncomfortable territories of race, power and politics for which they are ill-prepared. The phenomenon of decolonisation of texts in HEIs could also leave non-indigenous editors lacking in skills to negotiate these areas and the development of a model for ethical cross-cultural author-editor relationships should be considered.

Freeman (2009, p. 142) referring to aboriginal texts, states that editors 'take great care with the writer's words, endeavouring to assist in the production of a manuscript that is as good as it can be for a defined readership, demonstrating their understanding of the sanctity with which they must regard the author's voice". She continues by referring to the powerful position that editors find themselves in and the power increases if the cultural backgrounds of the editor and writer are different, for example, non-indigenous editors editing indigenous work.

Margaret McDonell (2004) refers to the "mediating impact of the editorial process" and goes on to say that a non-indigenous editor's purpose is scrutinised more intensely and there is a higher level of self assessment with the editor questioning the best way to perform editorial functions. 


\section{Results and Discussion}

Heleta (2016) refers to educators as being responsible for "unveiling the reality" and states that it is essential for academics and lecturers to take the initiative rather than waiting until "the institutional cultures and environments transform". It is within their own learning space that decolonisation should take place and there should be democratisation, while involving the learners in the process.

Part 1 of this study undertook to critically analyse the literature in an attempt to understand the reasons for the delay in change. The main problems point to the history of South Africa, where an African-centred curriculum was cast aside in favour of a Eurocentric approach under the apartheid era and this was aggravated by the linguistic hegemony with constant battles between English and Afrikaans as the dominant languages.

Part 2 of the study examined educator perspectives, while identifying educators as editors of decolonised and Africanised texts in curriculum development. Diversity of languages and cultures should be embraced, rather than focussing on holding onto established language norms and the expectations of exonormative correctness, with the view that English is the participants' lingua franca (Smit, 2005, p. 63). More emphasis could be placed on the acceptance of an endonormative standard for English that moves away from rigid rules and is more suited to the communication and practical needs of the people from the 11 different language groups within South Africa.

A decolonised English should include negotiability and variability in terms of speaking proficiency and an openness to the integration of forms of other languages as identified by House (2003, p. 557).

Globalisation has led to the increase of English as the language of communication, business transactions and research. Coleman (2006, p. 10), in a study of the growth of English-medium education in Europe, concluded that the people of the world are headed towards an identity that embraces a bilingual linguistic repertoire and a bicultural character. This will result in the world becoming diglossic and having a single language for "local communication, culture and expression of identity and another - English - for wider and more formal communication, especially in writing" and an identity that partially is rooted in the local culture but another part that arises from being aware of their relationship with a global culture (Coleman, 2006, p. 11).

It is recommended that the demographics of the relevant HEI be considered before undertaking any decolonisation process. Educator perspectives point to a mindset lacking in knowledge of why change should happen as well as whether it should happen. It would be a good idea to promote workshops or conferences on decolonising process where educators could be enlightened on the process and encouraged to participate in the change.

Part 3 of the study identified two strategies in the socio-cultural commitment when decolonising or Africanising texts, namely the use of proverbs and the development of a model for ethical cross-cultural collaboration during the editing process.

\section{Limitations and Further Research Opportunities}

It is acknowledged that a further study could be conducted with a larger sample from specific universities and provinces to discover the differences between the universities in the process of decolonisation and Africanisation. This study is too small to be used as a generalisation for all universities in South Africa. Further research should include understanding the role of the editors and educators in the production process of decolonised texts in higher education as well as what constitutes decolonised texts in higher education. An analysis of different higher education institutions within the country and their specific needs should also be considered for further investigation.

\section{References}

ALEXANDER, N., 2011, After apartheid: the language question. In: After Apartheid: The Second Decade, edited by I. Shapiro and K. Tebeau (University of Virginia Press). Date of access: 12/03/2019 http://www.yale.edu/macmillan/ apartheid/ alexanderp2.pdf 
BAMISILE, S., 2008, Socio-cultural commitment in things fall apart. When Things Came Together: Studies on Chinua Achebe. Date of access 25/08/2019 file://C:/Users/Linda\%20Scott/ Downloads/SocioCultural_Commitment_In_Things_Fall\%20(1).pdf

BUSINESS DICTIONARY, 2019, Editing. Date of access: 06/07/2019 http://www.businessdictionary. com/ definition/editing.html

COLEMAN, J. A., 2006, English-medium teaching in European higher education. Language Teaching, 39(1), 114.

DAVIDS, N., and WAGHID, Y., 2016, \#FeesMust Fall: History of South African student protests reflects inequality's grip. Mail and Guardian, 10 October. Date of access: 05/04/2019 https://mg.co.za/ article/2016-1010-feesmustfall-history-of-south-african-student-protests-reflects-inequalitys-grip

DEPARTMENT: HIGHER EDUCATION AND TRAINING, 2017, Statistics on post-school education and training in South Africa 2015. Date of access: 03/04/2019 www.dhet.gov.za

FREEMAN, R., 2009, 'We Must Become Gatekeepers': Editing Indigenous Writing. New Writing, 6(2), 133149.

FUSCH, P. I. and NESS, L. R., 2015, Are we there yet? Data saturation in qualitative research. The Qualitative Report, 20(9), 1408-1416.

HELETA, S., 2016, Decolonisation: academics must change what they teach and how. The Conversation, 20 November. Date of access: 10/06/2019 https://theconversation. com/decolonisation-academics-must-changewhat-they-teach-and-how-68080.

HORSTHEMKE, K., 2004, Knowledge, education and the limits of Africanisation. Journal of Philosophy of Education, 38(4), 571-587

HOUSE, J., 2003, English as a lingua franca: a threat to multilingualism? Journal of Sociolinguistics, 7/4, 556578.

JANSEN, J., 2017, The lost scholarship of changing curricula. South African Journal of Science, 113, 5-6.

KEHDINGA, D., and FOMUNYAM, G., 2017, Decolonising teaching and learning in engineering education in a South African university. International Journal of Applied Engineering Research, 12(23), 13349-13358.

LAENUI, P., 2006, Processes of decolonization. Date of access: 12/07/2019. http://www.sjsu.edu/people/ marcos. pizarro/maestros/Laenui.pdf

LE GRANGE, L., 2016, Decolonising the curriculum. South African Journal of Higher Education, 30(2), 1-12

MACGREGOR, K., 1996, Getting to grips with Africanisation. Higher Education Review/ Sunday Independent Supplement, May 19.

MAKGOBA, M. W., 1997, Mokoko: The Makgoba Affair - A reflection on Transformation (Florida: Vivlia).

MCDONELL, M., 2004, The invisible hand: cross-cultural influence on editorial practice, M Phil Thesis, University of Queensland.

NDLOVU-GATSHENI, S. J., 2016, Decolonizing the university and the problematic grammars of change in South Africa. Keynote address delivered at the 5th Annual Students Conference on Decolonizing the Humanities and Social Sciences in South Africa/ Africa. University of KwaZulu-Natal, 6-7 October 2016.

ODORA HOPPERS, C. A., 2000, African voices in education: retrieving the past, engaging the present, and shaping the future. In: African Voices in Education, edited by P. Higgs, N. C. G. Vakalisa, T. V. Mda and N. T. Assie-Lumumba (Lansdowne: Juta.)

RAMOSE, M. B., 1998, Foreword. In: Black Perspectives in Tertiary Institutional Transformation, edited by S. Seepe (Johannesburg: Vivlia).

RAMOSE, M. B., 2002, The struggle for reason in Africa. In: Philosophy from Africa, edited by P. H. Coetzee and A. P. J. Roux (Cape Town: Oxford University Press Southern Africa).

RAMOSE, M. B., 2004, In search of an African philosophy of education. SAJHE, 18(3), 138-160.

RITCHIE, J., LEWIS, J., NICHOLLS, C. M., and ORMSTON, R., (Eds), 2013, Qualitative research practice: a guide for social science students and researchers (Thousand Oaks, CA: Sage).

SCOTT, L. 2015. English lingua franca in the South African tertiary classroom: recognising the value of diversity, Master's thesis, Stellenbosch University. 
SILVA, P., 1997, South African English: Oppressor or liberator? The major varieties of English. Papers from MAVEN 97, Vaxjo, 20-22 November 1997.

SMIT, U. 2005. Multilingualism and English. The lingua franca concept in language description and language learning pedagogy. In: Mehrsprachigkeit und Kommunikation in der Diplomatie, edited by R. Raistauer, C. Cali, I. Cullin and K. Chester (Favorita Papers 4. Vienna: Diplomatic Academy), pp. 66-76.

SAHO, SOUTH AFRICAN HISTORY ONLINE, Student protests in democratic South Africa, Date of access: 20/05/2019. https://www.sahistory.org.za/article/student-protests-democratic-south-africa

SOUTH AFRICAN GOVERNMENT, 2019, History, Date of access: 20/05/2019. https://www.gov.za/aboutsa/history

SOUTH AFRICAN TRUTH AND RECONCILIATION COMMISSION (TRC), 2018, Welcome to the Truth and Reconciliation Commission Website, Date of access: 12/07/2019. http://www.justice.gov.za/trc/

STATISTICS SOUTH AFRICA, 2018, Mid year population estimates 2018, Date of access: 10/05/2019. www.statssa.gov.za

STRAUSS, A., \& CORBIN, J., 1990, Basics of Qualitative Research: Grounded Theory Procedures and Techniques (Newbury Park, CA: Sage).

THIONG'O, N. W., 1986, Decolonising the Mind: the Politics of Language in African Literature (Oxford, England: Heinemann).

WRIGHT, A., 2002, Politics of writing. Southerly, 62(2), 10-20.

SOCIO-CULTURAL COMMITMENT IN THINGS FALL APART Bamisile Sunday Adetunji* 